\title{
An Analysis of How Private Art Institutions Evaluate their Digital Presence During COVID-19
}

\author{
Nilay Dursun \\ Doktora Öğrencisi \\ Galatasaray Üniversitesi \\ Medya ve İletişim Çalışmaları \\ ndursun2@gmail.com \\ ORCID: 0000-0002-6902-6837
}

\begin{abstract}
Digital media has proven its importance during the COVID-19 lockdown by bringing citizens together and providing a virtual space to be creative. Therefore, art institutions have reconsidered their online presence and expanded their digital capabilities focusing on their corporate websites and social media accounts. Diverse research has been conducted addressing museums' digital media usage during the lockdown, mostly in terms of numbers. To offer a different viewpoint, through an explanatory approach supported by a qualitative methodology, this study aims to understand how the digital media and communication teams of art institutions have evaluated this digital shift encountered during the pandemic. Considering the researcher's ease of access, this study has focused on the leading private art institutions in Istanbul. Four in-depth interviews were conducted with employees of Arter, Istanbul Modern, Pera Museum and SALT in January 2021. Correspondingly, concentrating on their digital activities, the experiences of the team members have been shared.
\end{abstract}

keywords: Museum studies, digital media, COVID-19, social media, pandemic, art museums, digital communication 


\section{Résumé}

\section{Une Analyse de la Façon dont Les Institutions Artistiques Privées Évaluent Leur Présence Numérique Pendant COVID-19}

Les médias numériques ont prouvé leur importance lors du verrouillage du COVID-19 en rassemblant les citoyens et en offrant un espace virtuel pour être créatif. Par conséquent, les institutions artistiques ont reconsidéré leur présence en ligne et élargi leurs capacités numériques en se concentrant sur leurs sites Web d'entreprise et leurs comptes de médias sociaux. Diverses recherches ont été menées sur I'utilisation des médias numériques par les musées pendant le verrouillage, principalement en termes de chiffres. Pour proposer un regard différent, à travers une approche explicative soutenue par une méthodologie qualitative, cette étude vise à comprendre comment les équipes médias numériques et communication des institutions artistiques ont évalué ce virage numérique rencontré lors de la pandémie. Compte tenu de la facilité d'accès du chercheur, cette étude s'est concentrée sur les principales institutions artistiques privées d'Istanbul. Quatre entretiens approfondis ont été menés avec des employés d'Arter, d'Istanbul Modern, du Pera Museum et de SALT en janvier 2021. Parallèlement, en se concentrant sur leurs activités numériques, les expériences des membres de l'équipe ont été partagées.

mots-clés: Etudes muséales, médias numériques, COVID-19, médias sociaux, pandémie, musées d'art, communication numérique 


\section{Öz}

\section{COVID-19 Döneminde Özel Sanat Kurumlarının Dijital Varlıklarını Nasıl Değerlendirdikleri Üzerine Bir Analiz}

Dijital medya araçları, COVID-19 karantina dönemi sırasında insanları bir araya getirerek ve yaratıcı olabilmeleri için sanal bir alan sağlayarak, günlük hayatımızdaki önemi bir kez daha kanıtladı. Bu nedenle, sanat kurumları çevrimiçi varlıklarını yeniden gözden geçirdiler ve dijital yeteneklerini kurumsal web sitelerine ve sosyal medya hesaplarına odaklanarak genişlettiler. Kapalı kalınan süre içinde, müzelerin dijital medya kullanımlarını ağırlıkla sayısal veriler aracılığıyla ele alan çeşitli araştırmalar yapılmıştır. Farklı bir bakış açısı sunabilmek adına bu çalışma, nitel bir yöntem ile desteklenen açıklayıcı bir yaklaşımla, sanat kurumlarının dijital medya ve iletişim ekiplerinin pandemi sırasında deneyimledikleri dijital değişimi nasıl değerlendirdiklerini anlamayı amaçlamaktadır. Araştırmacının erişim kolaylığı göz önüne alındığında, bu çalışma istanbulıun önde gelen özel sanat kurumlarına odaklanmıştır. Ocak 2021'de, Arter, Istanbul Modern, Pera Müzesi ve SALT adlı kurumların çalışanları ile dört derinlemesine görüşme gerçekleştirilmiştir. Buna paralel olarak, görüşülen ekip üyelerinin deneyimleri, dijital faaliyetlerine odaklanarak paylaşmıştır.

anahtar kelimeler: Müze çalışmaları, dijital medya, COVID-19, sosyal medya, pandemi, sanat müzeleri, dijital iletişim 


\section{Introduction}

Museums as institutions that preserve our common heritage, provide spaces that promote education, inspiration and dialogue; strengthen social cohesion, foster creativity and convey collective memory (UNESCO, 2020). The COVID-19 epidemic, which has affected the whole world since the beginning of 2020, also required museum audiences and physical environments to meet on digital platforms with an impulse to socialize through networking; and thus, museums have entered a period in which they had to present their collections and activities to the audience in virtual environments and required the digital participation of the audience through diverse platforms which museums offer (Karadeniz, 2020, p. 975). In reaction to the COVID-19 pandemic, museums have attempted to recreate the physical tour experience through alternative replacements using new online media tools (Burke, Jørgensen, \& Jørgensen, 2020).

Researchers, that will be mentioned later in this paper, have focused on the various aspects of the digital shift that museums have experienced during the pandemic, and international institutions have published reports regarding the effects and results of this change by sharing qualitative data. Likewise, articles addressing digital media use have been limited to illustrating online activities proposed by the museums such as virtual exhibitions, social media sharing and the rise of followers particularly. Within this framework, establishing a causal relationship, a study that covers how museum employees evaluate the process of decision making and implementation of digital media usage during the pandemic is needed.

Private art institutions, acting as museums, which aim to introduce artistic and cultural heritage and make these values sustainable by carrying them to digital environments in accordance with today's technologies, is under the scope of this study. The aim of this article is to investigate how these institutions' digital media, digital marketing and communication teams, who are in charge of developing the digital presence, set up their digital communication strategies, how decision-making mechanisms work, and what were the positive and negative experiences/consequences have been experienced, in a period when we are suddenly more dependent on digital media tools, platforms and online communication.

Unlike studies that rely on numerical data and focus on how the applied strategies are evaluated by users, this research studies the digital agenda behind the scenes. Instead of embracing a consumer-led perspective of a social phenomenon that has affected the whole world, this paper aims to enable a service-oriented analyze. In this way, researchers and interested parties working on museum studies can better understand how museums adopted, reshaped, revalued and advanced digital technologies, imposed during the pandemic. 
Throughout this article, firstly, the development of museums' digitalization process regarding the ways museums use digital tools and technologies will be discussed. Secondly, how various researchers studied the effects of COVID-19 will be briefly illustrated. Thirdly, with a focus on the private art institutions and museums located in Istanbul, the digital activities performed by Arter, Istanbul Modern, Pera Museum and SALT during the pandemic, which mostly refers to the lockdown period when the museums were closed in between March - June 2020, will be discussed. And finally, how the respondents of the institutions evaluate the digital shift imposed by the pandemic; what they have encountered during this process will be described within the framework of their relationship with the relevant online tools.

\section{Museums and Digital Shift}

Message explains the concept of "new museum" as institutions where new objectives are developed and produced in order to associate with society with an inclusive manner to make the 'disciplinary boundaries' indistinct (Message, 2006, p. 604). Therefore, museums, operating as visitor-centered sites rather than collection-driven organizations, are primarily associated with the ways they unite with the public and develop their atmosphere for new segments of the population (Shrapnel, 2012). Regarding the social frame of reference, art museums have been developing their public scope as well as redefining and expanding their responsibilities in an attempt to unite with their visitors more straightforwardly, focusing on what their audience experienced (Esmel-Pamies, 2009). Onur states that museums had to use today's digital technologies, that enables them to deliver their cultural heritage inventory to wide audiences (as cited in Oğuz, 2019, p. 24). Thus, postmodern museology which emerged in the second half of the 20th century, is based on building a mutual interactive relationship with the visitor (Onur, as cited in Oğuz, 2019, p. 24). By this means, through introducing new ways for exhibition design and enabling innovative programs, introducing the notion of technology at the heart of museum life; developing new agendas like directed or curator-led visits, offering certain seminars for different age groups; providing various activities such as workshops, discussions modern museums define their new structure as places which enable greater communication with audiences (Altunbaş \& Özdemir, 2012, p. 6).

"In a shift from a relatively static culture to a global, corporate and electronic culture that constantly invents and reinvents itself, we can come to know the art museum differently" (Oberhardt, 2001, p.5). Oberhardt argues that permanency cannot be discussed in the $21^{\text {st }}$ century where we are living in an era of transition, which we seek to discover distinct and modern connotations for the study of art and museum studies to be able to be more open to the transforming culture and the new norms it brings (Oberhardt, as cited in Pollock \& Zemans, 2007). Due to creating a more structured relationship between the museum and its audience (and perhaps new audiences), numerous scholars have addressed 
the strategies planned by museums examining the user interaction research that suggests innovative programs, primarily based on curatorial activities; the use of technologies and imaginative festive elements that include emerging digital technologies (Bourgeon-Renault, Urbain, Petr, Le Gall-Ely, \& Gombault, 2006); proposed methods to consume cultural and artistic works via measuring various visitor groups and their behaviors (Daenekindt \& Roose, 2017).

When discussing the outcomes of the process of digitalization, Erbay states that enriched interactive design and augmented reality applications, carried the museum works to a new virtual dimension, thus in the era of postmodern museology, museums started taking advantage of the opportunities provided by digital technologies (Erbay, 2017, as cited in Oğuz, 2019, p.24). Examining the changing nature of the museum studies regarding their 'digitalization' process, we notice that to encourage participation; present audiences with an enjoyable experience and more and to facilitate the distribution of cultural objects and creating awareness, museums have begun to utilize various technologies such as 3D graphics, panorama displays, augmented and virtual reality technologies, as well as interactive games (Collin-Lachaud \& Passebois, 2008).

In today's world, museums might well be "visited" 24 hours a day by means of what digital technology offers. Furthermore, digital opportunities provide visitors with diverse choices for engagement. Viewing exhibits, engaging in online debates, exchanging experiences, curating exhibitions, working with other audiences, and adding to museums' online collections are among the few benefits provided by the digitally-driven museums (Grincheva, 2018).

Social networking has been one of the prominent players in cultural organizations in order to establish a strong connection with the public. Moreover, when we discuss the experience of the online community, Grincheva (2018) suggests that the relevant audience needs diverse social and cultural events delineating online discussions through social networking sites. And studying all these online interconnections allows us to find:

(...) online traces which are constantly recorded in the digital realm as visitor comments, posts, likes, visits, or shares. This online data on virtual audience behavior provides opportunities for more nuanced and comprehensive audience research that aims to enhance relationships between institutions and the public. (Grincheva, 2018, p. 104)

The international conferences based on museums, and their digital presence have acknowledged the assessment of online museum practice and the time spent with multimedia apps as a significant trend (Esmel-Pamies, 2009). Therefore, these digital platforms and social media use were researched extensively under the digital museum and audience development studies. 
Finally, when we consider the museum studies regarding the digital activities of museums in Turkey, we notice that researchers mostly have touched upon broadly how museums respond to the digital shift, giving examples according to the concepts they have discussed.

Concerning the museum research in Turkey, it is significant to point out that museums in Turkey are most generally differentiated as state museums and private museums, according to their governing structure. Therefore, it is possible to see different managerial approaches evaluating these two categories. Also, not all institutions owning collections, creating temporary exhibitions and engaging with public via various activities and publications, identify themselves as museums, even though they act as a museum in most ways. Likewise, some of the organizations that were evaluated as a part of this research have different institutional structures that will specified under the sampling section of this paper.

To move on, researchers define museums in Turkey (either state or private), as cultural organizations that benefit from digital products to support the presence of their temporary and permanent exhibitions (Karadeniz, 2020, p. 981). Also, academics working on the field indicate that the museums in Turkey can be described as places where technology-driven tools are continually being used to create online content through new media applications (Erişti, 2016; Çıldır \& Karadeniz, 2014, as cited in Karadeniz, 2020). According to Karadeniz (2020), digital information guides, audio headset systems, impact-vision system installations, live painting applications, 3D information systems, layered holograms, virtual applications, touch screens, digital books, thematic simulations and virtual workshops are among the mostly used digital technologies can be seen at the museums in Turkey (p.981). With the digitalization process regarding the state museums, in 2012, 16 museums have started to be renewed with the contemporary museum understanding and in 34 new museums the implementation of new technologies has projected (Karadeniz, 2020, p. 981). Especially when we examine virtual presence of museums in Turkey, we discover various examples from both state and private museums. To illustrate, it is possible to take a virtual tour in 33 different state museums at the "sanalmuze.gov.tr" established by the Ministry of Culture and Tourism. Private museums also keep up with the digitalization processes; through preparing digital exhibitions based on their collections and temporary exhibitions; social media organs, live broadcasts, webinars and online workshops (Karadeniz, 2020, p. 981).

Since there are not many detailed resources analyzing the web presence and social media usage in Turkey, in a recent research, Oğuz (2019) has analyzed 603 various types of museums in Turkey. It has been acknowledged that while $84 \%$ of the researched museums had a corporate website, $38 \%$ of these museum groups were using at least one of the social media platforms among Facebook, Twitter and Instagram (Oğuz, 2019, p. 110). Moreover, according to the research, when the social media usage performance is examined, it has learned 
that most of the museums that actively use these platforms are located in Istanbul and have a management structure dependent on the private foundations (Oğuz, 2019, p. 111). Likewise, Parseyhan have analyzed 62 private museums in Istanbul and pointed that $36 \%$ of the researched museums have invested in social media and web services, while using digital technologies only prior to and after the visit; accompanied with the social media use, $24 \%$ of the museums utilize digital technologies to improve the visit itself; and lastly the $16 \%$ the museums approach the visit itself as a means of immersive experience, through digitalizing their contents, using 3D screens surrounding the visitors, or by other interactive technologies (Parseyhan, 2020, p. 3540).

\section{COVID-19 and Museum Studies}

Museum activities across the globe have been interrupted by the COVID-19 pandemic, risking their financial sustainability and the wellbeing of thousands of museum workers (ICOM, 2020). (see Figure 1).

Figure 1. "Key Trends" presented by UNESCO (UNESCO, 2020, p.4).

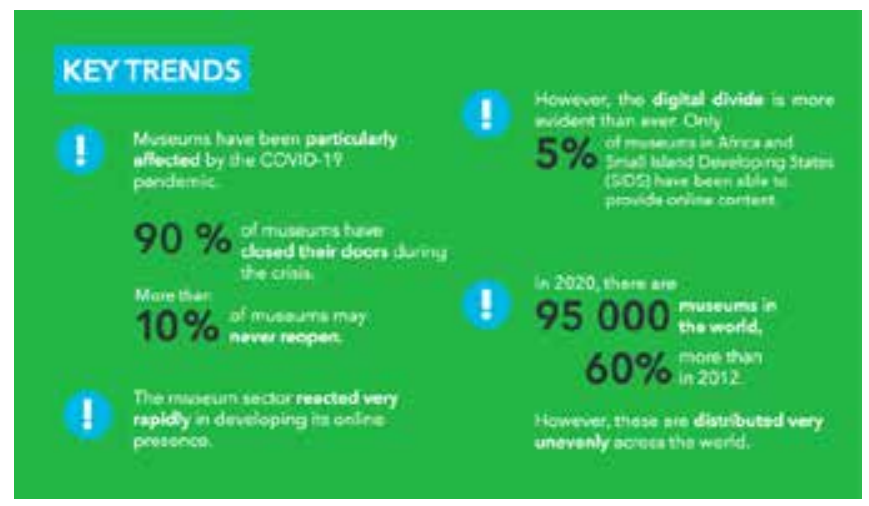

The need for museums to use technology effectively and increase their digital capabilities has become central to discussions in the field of cultural heritage with the global COVID-19 pandemic (Karadeniz, 2020, p. 984). Through their reaction to the pandemic, museums worldwide have sought to be fast and constructive, turning their attention to resolving challenges within their societies in this circumstance (NEMO, 2020). Hence, by growing their digital services to connect audiences who remain at home, museums have responded as quickly as possible to reduce the feeling of alienation and loneliness (NEMO, 2020). Either by presenting or re-presenting their previously digitized resources or creating new contents including online exhibitions, virtual tours, online educative 
workshops or informative videos about art and artists, different museums all around the world have found their way in the digital world during the pandemic. World-renowned museums such as the British Museum, the Metropolitan Museum of Art, the Louvre Museum, and the Hermitage Museum have entered into a great competition to bring their collections to the audience on digital platforms; and while updating their virtual museums and opened them to visitors, they have also created new virtual exhibitions and tours, also drawing attention to different studies on archeology and writing the history of the epidemic during the pandemic (Karadeniz, 2020, p. 976). It is also known that there has been a serious increase in the number of visitors of the virtual tours around the globe including Turkey (Karadeniz, 2020, p. 982). UNESCO has shared a figure regarding the distribution of digital response types of the researched museums in its report and illustrated the results regarding the digital responses by region (see Figure 2). According to the figure, while having utilized from previously digitized resources (cat. 1), museums categorized under the Western Europe \& Others including Turkey, have also presented online versions of exhibitions and events (cat.2). Moreover, while using social media as a means of communication (cat. 3), museums under this category have used other media to create and share new content offering educational and creative activities (cat. 4) contrary to other regions (UNESCO, 2020).

Figure 2. Distribution of digital response types presented by UNESCO (UNESCO, 2020, p.17)

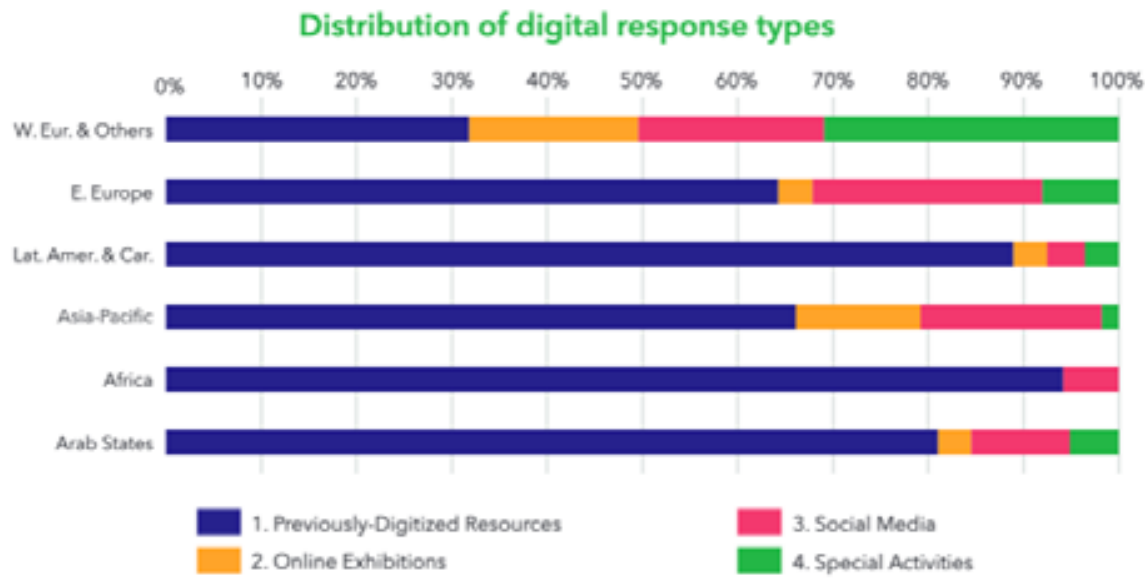

While most museums utilize social media more than ever, there has been a change in the development of interactive tours and online displays since cultural institutions wanted to engage with their audiences via multiple products. Museums have established their appropriate educational function digitally by delivering online quizzes, and instructional resources, in addition to offering online 
exhibits and interactive museum tours (NEMO, 2020). A respectable number of museums are now considering being more interested in the production of podcasts, live content and this leads to them seeking input and involvement from the online communities they are reaching out to (NEMO, 2020). ICOM has analyzed the changes in digital services regarding the usage of different digital tools before and during the pandemic to present how different museums communicate with their audiences (see Figure 3). According to the figure, for partly $15 \%$ of contributors, all the listed digital activities have either increased or started after lockdown and also nearly half of the contributors have begun presenting online activities through social networks or increased their usage (ICOM, 2020).

Figure 3. Changes in digital services presented by ICOM (ICOM, 2020, p.10)

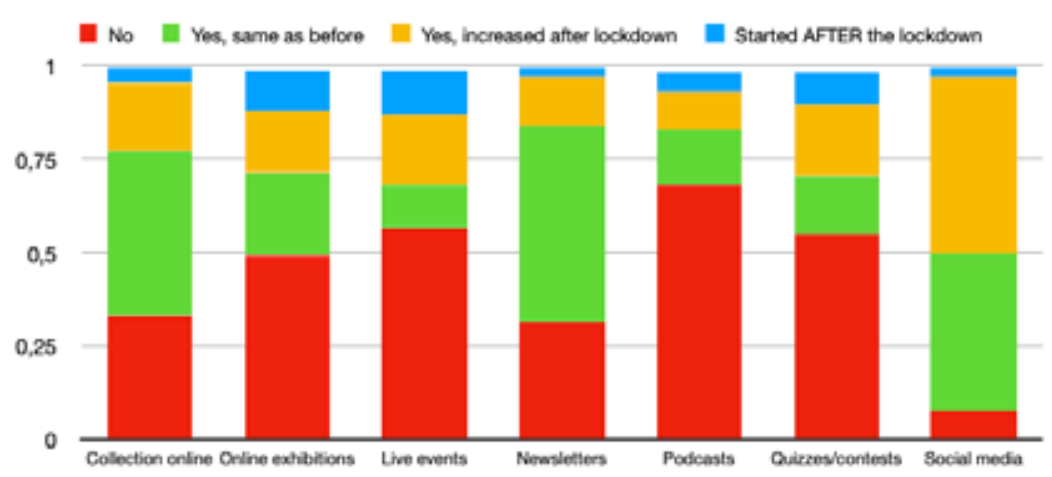

While it is still challenging for certain museums to carry out some operations, significantly moderate services, it is inevitable that this crisis would have a lasting effect on how cultural institutions engage with their audiences (ICOM, 2020).

In order to collect data about how the current crisis of COVID-19 effected and could influence the cultural field in the short and long term, most known institutions relating to the arts and museum sector such as ICOM, NEMO, ArtFund, UNESCO established national surveys to examine the effects of the lockdowns, as referred above, and focused on digital resources and communication; online activities on social networks; investment in digital technology, digital cultural heritage and the use of these networks; the quick and compliant digital skills and infrastructure, among other impacts of the pandemic.

Various writers have conducted comprehensive research to exemplify the digital activities of museums (Karadeniz, 2020); investigate how the museums deal with the COVID-19 global crisis by putting digital and virtual applications into effect (Erkmen, Kılıç, \& Kutsal, 2020); map innovative approaches of museums 
regarding the strategies adopted (Zbuchea, Romanelli, \& Bira, 2020); understand which traditional patterns of consumption have been affected concerning the digital cultural experience (Radermecker, 2020); examine alternative replacements making use of online platforms (Burke, Jørgensen, \& Jørgensen, 2020) digital communication of museums and the increased online participation of the audiences (Diamantopoulou, 2020); acknowledge how the pandemic has affected museology studies through exemplifying the usage of new media tools from Turkey (Kasapoğlu Akyol, 2020).

\section{The Purpose, Method and Sampling of the Research}

As the goal of this paper was to drill down into the impact of COVID-19 and illustrate different aspects that museums and art institutions faced regarding their digital presence, the research is qualitative in nature. To be able to fully understand the general state of museums during the pandemic, researchers should not only concentrate on examining numbers of scope, interactions, and posts in terms of using digital media resources. Since qualitative analysts are becoming more concerned in questioning how and why issues were taking place and evaluating perspectives, attitudes and behaviors (Creswell, 2016), this study design offers respondents the ability to be responsive in their answers and extend the discourse. For this purpose, to investigate how museums responded to what pandemic and lockdown brought with respect to digital activities, four in-depth interviews have conducted with people who work at the digital marketing and communication departments of Arter, Istanbul Modern, Pera and SALT, with their consent on recording.

As qualitative research aims to reveal how the participants perceive, conceptualize and evaluate the events instead of a numerical representation, indepth interviewing was used from data collection techniques (Rafiq, Batool, Ali, \& Ullah, 2021). Employees of four private art institutions in Istanbul, who works under digital communication and marketing departments were interviewed (see Table 1). While having a general information about the digital communication strategies of the institutions and how they have been practiced before and after the pandemic, the following concepts have discussed with the interviewees regarding their experience of:

- using various digital media tools and platforms

- content creation process for digital communication

- resource management in terms of new media usage

- presenting online curatorial activities, during the pandemic.

Also they were asked to evaluate the challenges and advantages of this period and their future plans in terms of digital media usage. The talks were held during January 2021. Three of the four interviews were conducted via Zoom and were recorded with the consent of the participants and deciphered together 
with the notes taken during the interview. One of the interviews was conducted by phone. The duration of the meetings varies between 50 to 60 minutes. The participants identified below (see Table 1), which were aimed to be interviewed with purposive, typical case sampling, have been selected due to their easy accessibility as used in convenience sampling.

Table 1. Interviewee Information

\begin{tabular}{|l|l|l|}
\hline $\begin{array}{l}\text { Intervieweed } \\
\text { Institution }\end{array}$ & Position & Code \\
\hline Arter & Media and Marketing Specialist & 11 \\
\hline Istanbul Modern & Digital Marketing Manager & 12 \\
\hline SALT & $\begin{array}{l}\text { Institutional Communication } \\
\text { Specialist }\end{array}$ & 13 \\
\hline Pera Museum & $\begin{array}{l}\text { Digital Projects and Social Media } \\
\text { Supervisor }\end{array}$ & 14 \\
\hline
\end{tabular}

Concentrating on their corporate websites, Istanbul Modern describes itself as an institution which was established in 2004 as Turkey's first modern and contemporary art museum, dedicated to expressing the creative imagination and cultural identity of Turkey with the locally and internationally art worlds, through facilitating a full variety of interdisciplinary programs (Istanbul Modern); SALT is identified as a cultural organization providing research-based exhibits, publications, web-based and multimedia services, as well as creating programs, delivered through SALT Beyoğlu and SALT Galata in Istanbul and to SALT Ankara (SALT). Moreover, established in 2010 as an affiliate of the Vehbi Koç Foundation, Arter is defined as a sustainable, lively cultural center providing a large variety of services that are open to everyone (Arter). And lastly, Pera Museum was opened in 2005 and is a private museum founded by the Suna and the Kıraç Foundation, aiming to offer an outstanding range of diverse, high-quality cultural and artistic services (Pera Museum).

The institutions included in this analysis may be expected to present a suitable scenario in regard to the various corporate identity features that the private museums in Istanbul hold. The researcher was unable to contact a significant number of respondents owing to the pandemic situation in the world and the density of the workload that the new media and communication departments contend with. However, this limitation was tried to be resolved by holding in-depth interviews which help to see the topic from different perspectives.

The results of the data that emerged after the in-depth interviews were presented to the reader by using the descriptive analysis method defined by summarizing and interpreting the data obtained according to previously deter- 
mined questions and themes (Yıldırım \& Şimşek, 2016, p. 238), in conjunction with the results of previous research, which already presented.

\section{Findings and Discussion}

\section{A general look at the usage of digital media tools before COVID-19}

The use of digital media tools in museums generally aims to maintain interaction with visitors, collect data about them, to remind the activities and programmes offered to the existing audience regularly and to provide information to new visitors (Erkmen et al., 2020, p. 274). While museums are adapting the inter-museum communication channels to develop technology, they can obtain faster and more measurable data via social media and websites instead of using classical communication tools had their grounds outside the museum (Erkmen et al., 2020, p. 274).

It has been indicated that the interviewed institutions' digital activities had started long before the pandemic, and especially for the last five years, utilizing social media consciously was at the center of their communication agenda. When we examine the most popular digital media platforms that all the institutions make use of, we can notice that they all have a Web page, Youtube, Instagram, Facebook and Twitter accounts. Therefore, the investment relating to the usage of digital media tools was already made years ago. However, three of the institutions have mentioned that they are on the verge of developing a new Web page to present a more user-driven design, language and interface. Moreover, although each museum has a Linkedin account, it would not be wrong to say that this is the least used or less significant account among other media tools. Finally, tools revolving around sound and music, such as Spotify or Soundcloud, were the only ones not used by all the institutions. For example, while Pera Museum and Arter have their Spotify accounts, the others do not. And it is essential to point out that the ones who have the account only use it to create playlists, which means they do not create original content such as podcasts etc. Uniquely, only Arter utilizes Soundcloud to share audio content prepared for the exhibitions. In addition to the digital tools mentioned above, all the institutions state that e-newsletter delivery is a significant part of their online and digital communication.

As indicated, all the institutions emphasized that they have a structured digital system before COVID-19, which was helpful for them to maintain their communication during the lockdown period. To examplfy, the interviewee representing SALT, briefly refers to their digital presence before and during the pandemic below.

In fact, we were open to sharing through different digital tools before the pandemic. Since our aim is for users to reach our archive, which also exists dig- 
itally, we have started to evaluate our contents under different headings again. (I3, SALT, Personal Interview, January 24, 2021)

\section{During COVID-19}

\section{Corporate Websites}

While evaluating the websites first, the interviewees were asked about their institutions' general approach regarding how they regulate their websites and other websites they utilize and were there any changes in terms of usage.

In the case of how the institutions utilize their websites, it has been noted that Pera Museum sees its website as an online museum. In other words, they believe that visitors should reach every information regarding what the museum presents to them through their website. "We should not consider digital tools, separately from the museum," says the interviewee representing Pera Museum (14, Pera Museum, Personal Interview, January 14, 2021). This includes the artworks, exhibitions, programs, and events. Apart from operating as a reflection of the actual museum, Pera's website offers digital-only content to its visitors through re-evaluating their collection at Google Arts\&Culture. Acting in the same way, Istanbul Modern benefits from its website to inform its visitors about their calendar, create digital content for the online tools, allow online visitors to experience the 3D tours of the exhibitions, and reach a selection from the museum's permanent collection. Digital Marketing Manager of Istanbul Modern states that they consider their website as a library.

Diversly, SALT offers three different corporate websites. To be able to present the exhibitions and events of SALT Galata \& Beyoğlu, the institution prefers to use saltonline. Also linked to the mentioned website, presenting both physical and digital sources (SALT) to open a space for research the institution uses saltresearch. And lastly, SALT provides access to its famous archive collections via archives.saltresearch.org, which can be accessed from saltresearch.

After the general evaluation, the interviewees have been asked if and how the pandemic has affected the way that they operate their websites. All interviewees indicated that they either re-arranged their content at the homepage of their websites to announce what they are already offering to draw attention or they embedded new content such as the online exhibitions, videos, or films prepared during the pandemic.

We bring some of our content, which we believe to be more influential, up front either through banners, or pop-up screens, or by changing the frontend. For example, our collection or 3D virtual tours which we created long before the pandemic. Also, we wanted people to be aware that our museum shop was still working online, and our learning activities have moved to online channels such as 
workshops. As a result, during 2020, 800.000 visitors reached our website and the Web page's overall engagement increased by $30 \%$ percent. (I2, Istanbul Modern, Personal Interview, January 6, 2021)

While mentioning how they reshaped their homepage structure in terms of content, the institutions have also pointed how their reevaluation has affected the visitor numbers.

We were using our website more as an archive, but during the pandemic, we started using it as the front face of the content we create, by repositioning and changing the layout of the homepage. We presented works from our archives that are already on hand with newly curated themes on the research page. While doing that, we were also presenting web projects, and we thought about how we could adapt our content to today's agenda. Therefore, our website has got much more attention than the other actions we have taken; especially the view rate of our website of our digital archives increased twofold. (I3, SALT, Personal Interview, January 24, 2021)

It has been acknowledged that Arter presents a different perspective from other institutions in terms of how they use their website. Arter offers necessary information regarding the exhibitions and other programs, also giving a brief information about the institution, building and its facilities including its membership options. However, during the pandemic, it has been noted that to be able to engage with the audiences, online selections of video works titled \#playathome were presented on the museum website and workshops titled Show and Tell from Home were held through the online communication platform Zoom.

\section{Social Media (Facebook - Instagram - Twitter)}

The Digital Projects and Social Media Supervisor at Pera Museum indicates that since social media came out, the issue of accessibility has become prominent for them; "the more people we can reach and deliver our services to, the better for the museum." (I4, Pera Museum, Personal Interview, January 14, 2021). It is likely that not all the museums evaluate the issue of reach from the same perspective. The interviewee representing Arter states that increasing the posting frequency on social media during the pandemic to be able to achieve higher interaction rate or reach, was not the primary objective of Arter and discussed their motive as following.

We did not increase our frequency of social media sharing because we were already posting on a daily basis and focused on the type of content we can offer. And the driving force behind it was to mediate a sustainable interaction with art, as much as digital presence itself. (I1, Arter, Personal Interview, January 30, 2021) 
Generally, museums state that they make announcements from every social media account as a part of their communication strategy, so they usually share the same content on every platform. Likewise, below, Istanbul Modern's participant states in detail that they have tried to post all information on each social media platforms simultaneously.

We try to share every content on Instagram, Twitter and Facebook at the same time. We embedded the same content in different tools separately in order to create the same Istanbul Modern perception everywhere. However, the availability of broadcasting live talks on Facebook and Instagram have created their unique place among the other social media tools. We tried these live events in the pandemic period too. Also, since sharing video content has become essential during the lockdown, we distinguished the social media tools that enable us to utilize this feature the most from others. That's why our posting frequency has increased. We use Instagram stories more than the other tools, because it gives us the ability of sharing the same content repeatedly such as reminders for our events or announcements. (I2, Istanbul Modern, Personal Interview, January $6,2021)$

Similarly, when we discuss the posting frequency, Arter states that they have not changed their daily frequency because they prefer to be careful about over-posting. They wanted to maintain the ongoing posting traffic which their followers are used to. In like manner, not only for social media posting, but also for creating digital content in general, SALT also wanted to be patient during the pandemic and described the process as follows:

Unlike other museums, we were not in a rush to share new ideas and contents; we kept certain periods of time to understand the pandemic world after we closed. Although we had a busy schedule for sharing online contents, we still kept studying our current programmes and presented most of them digitally around September. (I3, SALT, Personal Interview, January 24, 2021)

We notice that social media is being used as a marketing tool and it has an essential part in some of the museums' general marketing strategy for informing people about offers, in addition to strengthening their hand for further co-operations on social media with its sponsors. Also, it has been acknowledged that producing content to bring art to people's lives and invite people to generate content together is another strategy developed during the pandemic. Likewise, when we consider the motivations behind the usage of digital tools specifically during the pandemic, another critical point to realize is that not all the institutions' main aim stayed the same. On the contrary, it has evolved. To illustrate the point, it is important to share what Pera Museum's participant indicated below:

While we were using social media to inform our followers about our 
exhibitions and events that are normally included in our calendar, we have changed this perspective through re-arranging and representing our old content on social media during the pandemic period. Social media tools, which were considered mainly as advertising and promotion channels by the institution in the past, are now seen as the museum itself. Therefore, thanks to new media tools we can navigate the digital environment more easily and our social media accounts have become richer in content, almost more than the physical environment. (14, Pera Museum, Personal Interview, January 14, 2021)

Moreover, thanks to the pandemic, institutions were more open to new ideas and therefore decisions have evolved for the better. It has been stated that the pandemic has opened the way for creating user-generated content in Istanbul Modern, for the first time. Embrace art with a rainbow project, where they invited children to paint rainbows inspired by Sarkis's work Rainbow from the museum's collection, can be given as an example as it is indicated below:

To be able to connect with more people who are stuck in their houses and to offer them creative activities that can be done with children, we benefit from user-generated content, and it made a big impact. (I2, Istanbul Modern, Personal Interview, January 6, 2021)

\section{YouTube and Vimeo}

Even though they both enable featuring motion videos elementally, in terms of evaluating their usage, YouTube and Vimeo must be considered separately. As mentioned in the first section regarding the website usage, all four museums have added new content to their websites, such as online movie screenings or a curated selection of video works from the collection or even online exhibitions formed to exhibit video works; therefore, they needed to embed these video formats via an appropriate digital tool. Although all the institutions have a YouTube account, it has been reported that they chose to use Vimeo to embed videos on their websites because it was a more convenient tool for doing so. However, when we consider reaching more people and following the new media trends followed by the majority, YouTube creates its unique space in our lives. Specifically, all the museums interviewed own a YouTube channel; it is mostly used as a tool that can be inferred as a platform that facilitates growing audiences and creating face-to-face communication (Anderson, 2010) and grounds for social engagement.

To dig further, we discover that all the museums' presence on YouTube dates back to 2011-12. While some museums were using it more frequently, some were not active users (see Table 2). Nevertheless, all the interviewees admit that the amount of content they have published on YouTube has increased during the pandemic. 
Table 2. Youtube Membership and Videos Posted

\begin{tabular}{|l|l|l|}
\hline Institution & $\begin{array}{l}\text { The date joined on } \\
\text { Youtube }\end{array}$ & $\begin{array}{l}\text { Numbers or videos added } \\
\text { (Feb 2021) }\end{array}$ \\
\hline Arter & February 2012 & 71 videos \\
\hline Istanbul Modern & November 2011 & 268 videos \\
\hline Pera Museum & September 2011 & 592 videos \\
\hline SALT & February 2011 & 427 videos \\
\hline
\end{tabular}

While talking about their YouTube strategy, the Digital Marketing Manager of Istanbul Modern stated that they have shared diverse content through YouTube.

Before the closure, we had already invested in our YouTube account, and we were using it as a video repository. We improved the way we use it regarding what it offers as a digital media tool during the pandemic, we renewed our channel and adapted it. Through sharing new video content, we started using YouTube more actively. Among these, we can count the ones our curators and educators talk about artworks from our collection or exhibitions; live or recorded videos of the events and talks held by the curatorial or cinema departments on Zoom; projects that we have created to archive the COVID-19 period through the eyes of artists; video works from our exhibitions and so on. I must indicate that we have also managed to broadcast live events on YouTube for the first time in the pandemic. (I2, Istanbul Modern, Personal Interview, January 6, 2021)

Therefore, it might be true to say that Istanbul Modern was one of the institutions that shared the most diverse content on YouTube.

In like manner, while Pera was creating YouTube exclusive exhibition contents through presenting the artworks, newly created videos about old exhibitions and artists, curator and artist talks or workshop videos; SALT has moved its famous "Thursdaycinema" to YouTube to continue showing movies, and also hosted talks and presentations. Likewise, Arter shared a prior exhibition content offering a 3D experience, or artwork videos, also including workshops and art historian talks.

Additionally, it has been stated that the YouTube Ads feature helped SALT the most, in terms of creating awareness among the possible visitors. "Proportionally, YouTube was the most interactive platform we make use of. (I3, SALT, Personal Interview, January 24, 2021) 


\section{Google Arts \& Culture, and 3D Tours}

As mentioned, Google Arts \& Culture has become really popular during the pandemic since it has enabled people to reach artistic content from various art institutions in their homes. That's why, so many museums around the world were providing content to be shared on the website as mentioned below:

People were really interested in what museums were sharing in Google Arts and Culture because they needed to take a breath with art. Therefore, the engagement statistics on the site has increased $100 \%$. (I4, Pera Museum, Personal Interview, January 14, 2021)

Correspondingly, the only institution which was not present on Google Arts\&Culture before the pandemic was Arter. With opening its new building in September 2019, they were preparing to launch their account and on International Museum Day in May 2020, they have also opened their first exhibition on Google Arts\&Culture, during the closure period. Likewise, Pera and SALT have increased their presence by adding new projects on Google Arts \& Culture. However, SALT utilizes Google Arts \& Culture mostly to promote their archival value in a unique way.

When we discuss the presence of 3D virtual tours, we realize that Istanbul Modern was benefitting from it before the pandemic period, and the most prominent reason behind having a virtual tour was documenting the old building that they now rebuild. As mentioned, through drawing attention to the virtual tour on their website and social media at the beginning of the lockdown period, the museum experienced a tremendous interest. For this reason, while Istanbul Modern was adding three more 3D virtual tours to its website during the pandemic, Pera and Arter have also shared their 3D exhibitions. However, both institutions indicated that the primary reason for having a 3D tour was to document the shows. Lastly, apart from its Google Arts \&Culture presence, SALT did not choose to offer a 3D exhibition tour during the pandemic because the physical experience proposes a critical value for the institution.

\section{Challenges Faced and Advantages Gained Throughout the Lockdown in General}

When the interviewees were asked about the challenges of the lockdown and its effects on digital media usage, the most common response was the issue of creating eligible content in a short time. For example, the interviewee representing Istanbul Modern states that being fast in this process was really important in order to transfer most of the contents to several online platforms simultaneously. Media and Marketing Specialist of Arter talks about the challenging parts of the pandemic period below: 
Adapting to the digital world during the lockdown was challenging since in Arter's programme physical presence has always been central. During this period, we searched for new ways to maintain our interaction with our followers and visitors through digital media and developed new formats with cross-departmental studies. (I1, Arter, Personal Interview, January 30, 2021)

Also, another aspect mentioned as a challenge was the process of persuasion. Since some of the museums were inexperienced in using specific digital tools, the teams responsible for digital communication had to convince the museum executives to change their previous digital strategy. For example, posting new content on social media, having new partnerships with other museums, attending the commonly used hashtag movements ${ }^{1}$ or using a specific digital media tool.

It has allowed us to break prejudices. Thanks to the closure of the museum during pandemic and the need for creating new content, we have developed the way we communicate with our audiences. (14, Pera Museum, Personal Interview, January 14, 2021)

Regarding the usage of new media tools that were not used before the pandemic, we found that the institutions had difficulties in choosing the right tool for sharing their content.

We had to learn many new tools; for example, we focused on Google Analytics and Adds. We had to decide whether to use YouTube, Zoom, or Vimeo. We worked to improve our infrastructure for movie screenings, made investments where we saw necessities such as buying stock images to create new content. We had to make new decisions, and there were sometimes unforeseen errors or uncertainties during the process. (14, Pera Museum, Personal Interview, January 14, 2021)

The importance of analysis and data has increased. We specialized in how to use different new media tools in terms of data analysis. This also helped us know more about our online visitors and propose new plans for the targeted audiences. Now we care more about understanding the visitor profile and demographics. (I2, Istanbul Modern, Personal Interview, January 6, 2021)

Correspondingly, the interviewee representing Istanbul Modern states that they have started working with an Innovation Consultant to better their usage of digital media tools and get the most out of them.

Another challenge to consider was also the changing nature of the sales channels. Although museums are non-profit-oriented institutions, they need re-

1 \#MuseumBouquet, \#MuseumSunshine 
sources in order to continue to bring their services to the public. For this purpose, some institutions had to start online sales activities or increase their work amount in existing channels. This brought to the agenda that digital tools should also be used for sales purposes. For instance, Istanbul Modern has collaborated with Artsy and Amazon to sell its products from the museum shop. This meant learning new interfaces to create a page and publish the necessary works. Of course, not all institutions opened themselves to new products and decided to sell via the existing tools. While Arter was selling books from its bookshop through online orders via e-mails, Pera Museum used the direct messaging tool of Instagram to share money transfer information. Here we should evaluate SALT differently from other museums since both venues of the museum are free of charge.

As an institution that offers free access to its venues, it was important for us to create more resources for the people. However, since we lost out on other incomes, such as renting places inside of our buildings, we needed to cut our marketing budgets that focus on the outdoors. Instead, we redirected that budget to social media marketing. (I3, SALT, Personal Interview, January 24, 2021)

To move on, since creating content for digital media platforms mostly became the principal goal, one can suggest that the digital media and communication departments of the museums were under more pressure. When asked about the challenges of the pandemic, it has been acknowledged that another critical point that was experienced during the lockdown was the excessive workload. When asked about how these departments managed their time and resources during the pandemic, it has been noticed that sharing the workload between different departments was a standard method used. Museum teams also pointed that the inter-departmental cooperation has increased during the process. Especially curatorial and education departments have worked hand in hand with the digital media departments. Even though people were not physically in the same office anymore, thanks to Zoom or Google Meet, they have started to spend more time working together even more than before and it has enriched the communication also between the museum staff. Likewise, not losing the communication helped employees to act fast as the Institutional Communication Specialist of SALT exemplifies:

Our practice of working from home and together have increased; we are more organized now. We realized that our intuitions and reactions were strong; we were able to convert a previous exhibition into a Google Arts \&Culture content in only two weeks. (I3, SALT, Personal Interview, January 24, 2021)

Similarly, the interviewees state that they have learned how important it is to make daily and weekly plans and sometimes not make any long-term plans.

When we discuss more on the positive results of this period, all interview- 
ees argue that the pandemic and lockdown period has been a very stimulating process to evaluate what can be done and what can be considered. Even though not all institutions decided to share everything digitally, it has been indicated that they all realized the importance of creating a qualified online archive. When talking about the advantages and positive achievements of COVID-19, all the institutions pointed out it was vital for them to reach people outside of Istanbul.

As an arts and culture institution we considered this period as an opportunity to reach our followers from various parts of Turkey, especially through our online programmes and workshops. We are happy to be in touch with people who were not able to visit Arter before. (I1, Arter, Personal Interview, January 30, 2021)

Likewise, it was indicated that SALT has also reached wide audiences in Turkey.

We reached people from different parts of Turkey, especially through our website of our digital archives. During this period, when students and academics had to work from home, we provided access to university academicians. Through sending e-mails, we informed them about the existence of the documents we have. We pioneered the establishment of a committee of researchers under the project named Ask an Expert and contributed to the online consultation through this board. It was crucial for us to increase the human touch and interaction relating to our activities. We have also conducted various online study groups focused on different research topics. Through these experiences, we reached a lot of people from different regions of Turkey. (I3, SALT, Personal Interview, January 24, 2021)

Similarly, with respect to the numbers relating to website reach, it has been stated that it was vital for Istanbul Modern that $48 \%$ percent of the museum's online visitors were people who live outside of Istanbul.

Another point that was touched upon from time to time while discussing other subjects with the institutions was how the pandemic period opened a space for new collaborations or reinforced and moved existing partnerships to digital platforms. Istanbul Modern has collaborated with Facebook for the first time and carried out four different live broadcasts under the theme of culture and art. Likewise, both Istanbul Modern and SALT moved their existing collaborations online via utilizing digital media tools. While Istanbul Modern was sharing video content as a part of their online exhibition under the project of Artist Film International; SALT created video content under the theme of Artists in Quarantine to support the conversation about the effects of the current pandemic, in collaboration with L'Internationale. 


\section{Conclusion}

It can be emphasized that the significance of the museums in our lives has increased during the COVID-19 crisis. People were looking for new ways to connect with art \& culture and also with communities that they have shared values. Museums are cultural organizations that aim to have a strong relationship with their audiences either physically or online and have experienced diverse ways of digital communication via diverse digital media platforms and tools during the pandemic. From interactive tours to e-learning tools, museums have used services in a number of ways so that their digital presence may offer a means to communicate with the public, in addition to exchanging exhibits and experiences and helping those in lockdown during the COVID-19 crisis. While some researchers have analyzed the outcome of this usage in terms of content, sharing and reach, this study focused on how this sudden crisis has affected the museums in terms of going deeper into the digital world and how it felt for the museum teams to experience this process with its advantages and challenges.

According to the research, it can be said that art institutions and museums were utilizing the digital world long before the pandemic. However, both the tools they used and the way they used them differed during the pandemic. Likewise, during COVID-19 museums have acted in diverse ways, with respect to the digital activities they offer. The interviewees stated that the pandemic has opened a space for new ways of communication, while also challenging the institutions.

Together with, it was understood that the institutions have also adopted different working principles at the time of lockdown in line with their visions. Also, since the pandemic prompted the museums to act fast, it has allowed for new decisions to be taken by the administrations of these organizations, regarding their digital communication. Finally, it was concluded that the transfer of the currently carried activities to digital platforms has improved the visitor profile of the museums so far, and therefore institutions decided to continue conducting online activities in order to reach diverse audiences.

As mentioned, museum studies under the scope of communication sciences which research the use of digital tools, are limited in Turkey. In this sense, this article will contribute to this new field which has recently found its place in the literature. In addition, considering the conducted studies in the field aim to exemplify the digital communication strategies of museums without discussing the personal experiences even though it is a very small and human-oriented sector, this research focusing on the experiences of the employees, who create and implement these strategies, will provide a new perspective to the field. Academics working in the disciplines of communication sciences, public relations, new media, museum studies and managers working in the field of culture and arts 
and strategy development can also benefit from this study.

Even though the scope of this article is limited to the studies and digital practices of the interviewed private art institutions in Istanbul, these findings may be valid for other examples too. However, other small scaled private museum and state museums should be examined for further research and realization to discuss the subject. Also including a quantitative approach to evaluate the presented content via digital communication tools and the effects of implemented strategies to understand how visitors responded to these strategies during the pandemic may present a broader approach in the field. As the coronavirus pandemic continues affecting our lives, art museums around the world and institutions of all sizes face unpredictable futures, with no definite date for the end of the crisis. Therefore, by conducting a broader study with a more elaborate scope, this research may be developed in a more integrated way by using a methodology offering a comparative design.

\section{Bibliography}

Altunbaş, A., \& Özdemir, C. (2012). Çağdaş müzecilik anlayışı ve ülkemizdeki müzeler. Retrieved 7 December 2020, from https://teftis.ktb.gov.tr/Eklenti/4655,makale.pdf

Anderson, C. (2012, June). How web video powers global innovation. TED Conferences. https://web.archive.org/web/20131202000212/http:/www.ted.com/ talks/chris_anderson_how_web_video_powers_global_innovation.html.

Arter. (n.d.). Retrieved February 5 2021, from https://www.arter.org.tr/en/about-us

Burke, V., Jørgensen, D., \& Jørgensen, F. A. (2020). Museums at Home: Digital Initiatives in Response to COVID-19. Norsk Museumstidsskrift, 6(2), 117-123. doi:10.18261/issn.2464-2525-2020-02-05.

Bourgeon-Renault, D., Urbain, C., Petr, C., Le Gall-Ely, M., \& Gombault, A. (2006). An Experiential Approach to the Consumption Value of Arts and Culture: The Case of Museums and Monuments. International Journal of Arts Management, 9(1), 35-47.

Collin-Lachaud, I., \& Passebois, J. (2008). Do Immersive Technologies Add Value to the Museumgoing Experience? An Exploratory Study Conducted at France's Paléosite. International Journal of Arts Management. 11(1), 60-71.

Creswell, J. W. (2016). Essential skills for the qualitative researcher . 1-292.

Daenekindt, S., \& Roose, H. (2017). Ways of preferring: Distinction through the 'what' and the 'how' of cultural consumption. Journal of Consumer Culture, 17(1), 25-45. doi:10.1177/1469540514553715.

Diamantopoulou, S. (2020, August 17). Retrieved from Experiencing the digital museum at the time of the pandemic: The ethics of multimodal communication with the visitors: https://panmemic.hypotheses.org/778 
Erkmen, A., Kılıç, M., \& Kutsal, D. (2020). Accessibility of Art Museums in Istanbul during the COVID-19 Pandemic: An Evaluation via Social Media and Digital Applications. MSGSÜ Sosyal Bilimler Dergisi, 2(22), pp. 271-289. Retrieved December 16, 2020.

Esmel-Pamies, C. (2009). Into the politics of museum audience research (Masteris thesis). Retrieved from: [E]dition 5 Tate Encounters.

Grincheva, N. (2018). Researching online museums: Digital methods to study virtual visitors. In I. levenberg, T. Neilson, \& D. Rheams (Eds.), Research methods for the digital humanities (pp. 103-128. ). Palgrave Macmillan.

ICOM. (2020, May 26). Museums, museum professionals and covid-19: Survey Results.

Retrieved from https://icom.museum/en/news/museums-museum-professionals-and-covid-19-survey-results/

Istanbul Modern. (n.d.). Retrieved February 2 2021, from https://www.istanbulmodern.org/en/museum/about_760.html

Kasapoğlu Akyol, P. (2020). Covid-19 Küresel Salgın Dönemi ve Sonrası Müze Etkinlikleri. Millî Folklor, 32(16), 72-86. Retrieved from https://dergipark.org.tr/tr/ download/article-file/1192049.

Karadeniz, C. (2020). Müzede Dijital Teknolojilerin Kullanımı ve Salgın Sürecinde Dijital Katılım. idil, 70, 975-984. doi: 10.7816/idil-09-70-06 .

Message, K. (2006). The New Museum. Theory, Culture \& Society, 23(2-3), 603606. doi:10.1177/0263276406023002110.

NEMO. (2020, May 12). Survey on the impact of the covid-19 situation on museums in Europe Final Report. Retrieved from

https://www.nemo.org/fileadmin/Dateien/public/NEMO_documents/NEMO_ COVID19_Report_12.05.2020.pdf

Oberhardt, S. (2001). Frames within frames: The art museum as cultural artifact. New York: Peter Lang.

Oğuz, I. (2019). Dijital iletişim sürecinde türkiye'deki müzelerin yeri. Unpublished master's thesis. Dokuz Eylül Üniversitesi, İzmir

Parseyhan, B. G. (2020). Digital Transformation in Museum Management: The Usage of Information and Communication Technologies. Turkish Studies - Social Sciences, 15(8), 3539-3550. doi.org/10.47356/TurkishStudies.45995.

Pollock, G. and Zemans, J. (2007). Museums after modernism. Malden, MA: Blackwell.

Pera Museum. (n.d.). Retrieved February 1, 2021, from https://www.peramuse- 
um.org/Home/About

Radermecker, A. V. (2020). Art and Culture in the COVID-19 era: For a Consumer-oriented Approach. S. SN Business \& Economics, 1(1), doi:10.1007/s43546020-00003-y.

Rafiq, M., Batool, S. M., Ali, A. F., \& Ullah, M. (2021). University Libraries Response to COVID-19 Pandemic: A Developing Country Perspective. The Journal of Academic Librarianship, 47, 1-10.

SALT. (n.d.). Retrieved December 11 2021, from from https://saltonline.org/en/43 Shrapnel, E. (2012). Engaging young adults in museums an audience research study. Unpublished master's thesis.

UNESCO. (2020, May). Museums around the world in the face of covid-19. Retrieved from

https://unesdoc.unesco.org/ark:/48223/pf0000373530?fbclid=IWAR0JGX8DmJZUMIWPK7mMF8FDx4_x8FDJIYEOy0YO6jH63mBTjtQhhP_yN1w

Zbuchea, A., Romanelli, M., \& Bira, M. (2020). Museums in time of the covid-19 pandemic. $\quad$ Focus on romania and italy. Proceedings of Strategica 2020, 680705. Retrieved from https://www.researchgate.net/publication/345732637_ Museums_during_the_COVID- 19_pandemic_Focus_on_Romania_and_Italy

Yıldııım, A., \& Şimşek, H. (2016). Sosyal bilimlerde nitel araştırma yöntemleri. Ankara: Seçkin. 